Ecclesia. Studia z Dziejów Wielkopolski t. 13 (2018)

doi: 10.14746/e.2018.13.1

IGNACY LEWANDOWSKI

Uniwersytet im. Adama Mickiewicza w Poznaniu

Instytut Filologii Klasycznej

\title{
Wątki religijne w twórczości i życiu Klemensa Janickiego (1516-1543)
}

\section{Zarys życia i twórczości}

Klemens Janicki jest współcześnie postacią mało znaną, milczą o nim nauczyciele i podręczniki szkolne. Warto więc na wstępie przypomnieć choć $\mathrm{w}$ zarysie biografię i twórczość jednego z największych poetów łacińskich $\mathrm{w}$ Polsce ${ }^{1}$. Z okazji jubileuszu pięćsetlecia urodzin poświęcono mu trochę więcej uwagi, ale niestety tylko na Pałukach i w Poznaniu. W grodzie Przemysła niedaleko Starego Rynku stanął jego wspaniały pomnik, na Uniwersytecie im. Adama Mickiewicza zorganizowano ogólnopolską konferencję, podczas której wygłoszono o Janickim szereg interesujących referatów ${ }^{2}$. W pobliskim Gnieźnie jego imieniem nazwano małe rondo w pobliżu katedry. W Żninie, stolicy Pałuk, dzięki życzliwości Żnińskiego Towarzystwa Kultury ukazały się o „poecie uwieńczonym” (poeta laureatus), jak go stale określano, dwie monografie ${ }^{3}$, odbyła się również konferencja naukowa z wykładami badaczy Janickiego. W lokalnej prasie można było przeczytać o Klemensie kilka artykułów, na jego cześć urządzono biegi, które zgromadziły wielu za-

\footnotetext{
${ }^{1}$ Artykuł został opracowany na podstawie referatu wygłoszonego 24.10 .2018 r. w Domu Katolickim Parafii pw. św. Floriana w Żninie na zaproszenie Ruchu Kultury Chrześcijańskiej „Odrodzenie" (Oddział Żnin) i proboszcza tej parafii, ks. dr. Tadeusza Nowaka. Tamże przed niemal 500 laty uczęszczał do szkoły Klemens Janicki.

${ }^{2}$ Niektóre zostały opublikowane w czasopiśmie Instytutu Filologii Klasycznej UAM „Symbolae Philologorum Posnaniensium” 26/2 (2016); 27/3 (2017).

${ }^{3}$ I. Lewandowski, Poeta laureatus czyli Życie i dzieło Klemensa Janickiego, Żnin 2016, ss. 288; krótki wybór poezji w polskim przekładzie oraz ilustracje; A.Kuehn, Zdrowie Klemensa Janickiego $z$ apteka $w$ tle, Żnin 2016, ss. 77.
} 
wodników z całej Polski. Trzeba również podkreślić, jak wiele serca i wysiłku w uczczenie wieszcza włożyli nauczyciele i dzieci Szkoły Podstawowej imienia Klemensa Janickiego w jego rodzinnym Januszkowie. Tam bowiem, cztery kilometry od Żnina, w wieśniaczej zagrodzie, nie w dworku szlacheckim ani w pałacu magnackim, dnia 17 listopada 1516 roku, w samo południe urodził się nasz przyszły znakomity poeta.

Po ukończeniu szkoły parafialnej przy żnińskiej farze dwunastoletni chłopiec został studentem słynnej Akademii założonej przez biskupa Jana Lubrańskiego w Poznaniu na Ostrowie Tumskim. To tam - jak powie w elegii $O$ sobie samym do potomności - spotkał nauczyciela, który wspaniale przekazywał wiedzę o dokonaniach Greków i Rzymian. Prawdopodobnie był nim znakomity humanista niemiecki z Lipska, Krzysztof Hegendorf, luteranin, zwolniony później ze szkoły, a może - jak sądzą inni - nauczycielem tym był Tomasz Bederman, rodowity poznaniak, wychowanek Akademii Krakowskiej. Studia poznańskie na dobre otworzyły Klemensowi bramy do gruntownego poznania antycznej wiedzy. W uczelni nad Wartą, w cieniu gotyckiej katedry chłopski syn, młodzieniec o gorącym sercu, różnorakich talentach i bystrym umyśle chłonął wiadomości o rzymskich i greckich pisarzach, o artyzmie ich nieśmiertelnych utworów, o sposobach ich interpretacji. Szczególnie rozkochał się w dwóch poetach, Wergiliuszu i Owidiuszu, i zapragnął pójść w ich ślady. Zaczął więc, mając piętnaście lat, komponować wiersze łacińskie - najpierw o charakterze panegirycznym, z czasem także miłosnym, a w końcu nawet paszkwilanckim. Nic się z nich nie zachowało. Klemens jednak opuścił Akademię w sławie poety.

Od roku 1536 swoje literackie marzenia realizował w pobliskim Gnieźnie na dworze prymasa Polski, Andrzeja Krzyckiego, również utalentowanego poety. Jako bibliotekarz, a może i sekretarz, miał okazję poznać wiele osobistości ówczesnego życia kościelnego i politycznego, które bawił dowcipnymi wierszykami. Tu na cześć swego mecenasa napisał długie elegie pochwalne, a ten zlecił mu poetyckie opracowanie biografii arcybiskupów gnieźnieńskich (Vitae archiepiscoporum Gnesnensium; cyt. Arch.). Na dworze prymasowskim napisał także szereg krótkich epigramów opartych przeważnie na motywach biblijnych. Sielanka nie trwała jednak długo. Kiedy wśród prymasowskiej świty udał się na sejm do Krakowa, nieoczekiwana śmierć pozbawiła go ukochanego opiekuna (maj 1537). Zostanie w podwawelskim grodzie i już nigdy nie zobaczy Wielkopolski; będzie do niej wracał jedynie w poetyckim słowie oraz w nielicznych zapewne listach do rodziców, brata i znajomych.

Wkrótce jednak poeta znalazł nowego mecenasa, Piotra Kmitę, wojewodę krakowskiego, dumnego magnata, wpływowego i kontrowersyjnego polityka. Zaczął się więc obracać w kręgach ludzi świeckich - urzędniczych i wojskowych. Dzięki temu nie tylko odwiedzał południowe regiony państwa, uczest- 
niczył przy boku mecenasa - oczywiście na swoją miarę - w burzliwym życiu politycznym na sejmach i nawet w wojskowych zamieszkach na Kresach, w tzw. „wojnie kokoszej” pod Lwowem. Jednak nie to mu imponowało; myślał o peregrynacji do słonecznej Italii, aby tam studiować. Zanim zrealizował ten zamiar, zdążył na dworze Kmity skomponować utwory pełne troski o dobro ojczyzny, jak Querela Rei Publicae Regni Poloniae - „Skarga Rzeczypospolitej Królestwa Polskiego” (cyt. Quer.) czy Ad Polonos Proceres - „Do polskich magnatów” (cyt. Proc.). Wówczas także powstały dalsze utwory elegijne i epigramatyczne. A być może już wtedy z inicjatywy swego mecenasa zaczął poetycko opracowywać Vitae regum Polonorum - „Żywoty królów polskich” (cyt. Reg.)

W drugim kwartale 1538 roku chłopski syn z Januszkowa był już w dalekich Włoszech i zapisał się na listę studentów słynnego uniwersytetu w Padwie, gdzie w tym czasie humanistyczne wykształcenie na najwyższym poziomie zdobywało wielu synów bogatych rodów z całej Europy, w tym także z Polski. Jego mistrzem był między innymi znakomity retor i nauczyciel literatury łacińskiej, Łazarz Bonamicus. Niestety, Janickiemu doskwierały i niedostateczne środki finansowe, i - co gorsza - długotrwałe choroby. Musiał więc powrócić do kraju wcześniej, niż zamierzał. Ale jak na nieco ponad dwuletni pobyt miał osiągnięcia godne najwyższego podziwu, bo w ośrodku tak wyrafinowanej sztuki i nauki renesansowej, jakim była Padwa, zdobył stopień doktora nauk humanistycznych i filozofii oraz - jako jedyny Polak - otrzymał najwyższe europejskie wyróżnienie - laur poetycki (w ogóle drugi w Polsce). Tam też powstało, nie licząc epigramów, osiem pięknych i rzewnych elegii, które swoim kunsztem oczarowały wytrawnych recenzentów i znawców łacińskiej poezji, wśród nich także kardynała Piotra Bembo, znakomitego filologa i historyka, prozaika i poetę, który zapraszał Janickiego na literackie spotkania do swoich ogrodów.

Jesienią 1540 roku poeta znalazł się znów w Krakowie, lecz ani klimat ziemi ojczystej, ani troskliwa opieka lekarza Antonina nie potrafiły przywrócić mu zdrowia, którego zresztą nie miał od dziecka. Chorując na puchlinę wodną, żyjąc stale w cieniu śmierci, nie wypuszczał jednak pióra z ręki. Pomoc Kmity ustała, skromne środki utrzymania dawały mu honoraria i kościelna prebenda najpierw w Koniuszy pod Proszowicami, a później w Gołaczowie pod Olkuszem.

Lata 1541-1542 cechowała szczególnie wzmożona twórczość i zbieranie dorobku; ogłosił wówczas dialogową satyrę In Polonici vestitus varietatem et inconstantiam dialogus - „Dialog przeciw różnorodności i zmienności polskiego stroju", skomponował wiele elegii i epigramów oraz obszerny, dwuczęściowy Epithalamion Serenissimo Regi Poloniae Sigismundo Augusto - „Pieśń weselną dla Najjaśniejszego Króla Polskiego Zygmunta Augusta” (cyt. Epith.). W tym czasie, czując zbliżającą się śmierć, zebrał utwory, dodał nowe i wydał 
w jednym tomie zbiór elegii i epigramów pt. Tristium liber (cyt. Tr.), Variarum elegiarum liber (cyt. Var.), Epigrammatum liber (cyt. Epigr.), a więc „Księgę żalów”, „Księgę różnych elegii”, „Księgę epigramów” (Kraków 1542) ${ }^{4}$.

W pierwszej części, nawiązując wyraźnie do wygnańczej poezji rzymskiego poety Publiusza Owidiusza Nazona (stąd nazywa się go ,polskim Owidiuszem"), jako pierwszy w literaturze europejskiej stworzył zbiór rzewnych elegii związanych ściśle z własnym tragicznym losem i bardzo osobistymi przeżyciami. Podobnie jak Tristia nieszczęsnego rzymskiego wygnańca, młodzieńcze Tristia syna kmiecia spod Żnina jeszcze dzisiaj głęboko nas przejmują i wzruszają, gdyż są bezpośrednim dokumentem smutnego losu poety ciężko doświadczonego przez nieuleczalną chorobę. Wśród elegii znajduje się słynny utwór autobiograficzny De se ipso ad posteritatem - „O sobie samym do potomności”, w którym Janicki pozostawił poruszający obraz swego życia, swoich postaw, marzeń i dążeń.

„Różne elegie” drugiego zbioru są wcześniejsze, mają inny charakter, nastrój mniej osobisty, dużo bardziej pogodny, a nawet niekiedy radosny i żartobliwy.

Trzecia część wydania, „Epigramy”, jest również nowością na gruncie polskiej literatury, gdyż Janicki jako pierwszy w Polsce opublikował swoje krótkie wiersze w jednym zbiorze. Umieścił zaś w nim epigramy religijne, epitafijne, herbowe, miłosne, obyczajowe i okolicznościowe, które dotychczas były luźno puszczane w obieg. One również dają obraz życia społeczeństwa w Polsce epoki zygmuntowskiej.

Pod koniec 1542 albo na początku 1543 roku, gdy ukończył zaledwie dwadzieścia sześć lat, dopadła poetę - jak napisali jego przyjaciele - śmierć przyspieszona przepracowaniem. Został pochowany w Krakowie na nieistniejącym dziś cmentarzu obok kościoła Mariackiego. Nad jego grobem wśród znakomitych przyjaciół stała także rodzona matka z Januszkowa ${ }^{5}$.

\section{Wątki religijne w twórczości i życiu poety z Januszkowa}

Życie poety przypadło na burzliwy okres społecznych i religijnych przemian w Europie. Zaznaczały się wtedy zwłaszcza dwa kierunki: jednym był humanizm, a drugim reformacja. Pierwszy nurt był bardziej elitarny, obejmo-

\footnotetext{
${ }^{4}$ Najnowsze i najlepsze wydanie poezji Janickiego z polskim przekładem prozaicznym: Klemens Janicki, Carmina. Dzieła wszystkie. Wydał i wstępem (I) poprzedził J. Krókowski, przełożył E. Jędrkiewicz; wstęp (II), komentarz, similia, appendices, słownik imion własnych i indeks oprac. J. Mosdorf, Kraków 1966.

${ }^{5} \mathrm{O}$ życiu i twórczości Janickiego istnieje bogata literatura, zob. spis publikacji w: I. Lewandowski, Poeta laureatus..., s. 219-228.
} 
wał przede wszystkim kręgi ludzi wykształconych, bezpośrednio korzystających z dorobku antyku dzięki znajomości języków klasycznych, łaciny i greki. Fascynacja starożytnością niekiedy przybierała postać pogańską i stawała się nawet ideowym zagrożeniem dla religii katolickiej.

Drugi zaś nurt, reformacja, zaangażowany był głównie w przemiany religijne i kościelne oraz kierował się ku przebudowie całego społeczeństwa. Wnosił on nowe spojrzenie na dzieje ludzkie, świeckie i kościelne, oraz na organizację Kościoła i państwa jako dwóch równoprawnych czynników kształtujących oblicze mieszkańców Europy. Jeśli jednak humanistyczna wizja dziejów podkreślała coraz bardziej czynnik ludzki i redukowała działanie Bóstwa, to reformacja stale uznawała naczelną rolę Boga w historii i odcinała się od czysto ziemskiego jej traktowania. Te dwa nurty były żywe także w Rzeczpospolitej Obojga Narodów, ogarniały w tym czasie domy, kościoły, szkolnictwo na całym jej terenie. I nie mogły one pozostać bez wpływu na duchową formację Klemensa Janickiego, który dzięki swemu ojcu kmieciowi i mecenasom otrzymał staranne wykształcenie i wszedł do grona intelektualnej elity kraju.

Przystępując do właściwego tematu, pragnę tutaj mocno zaznaczyć, że łacińskie wiersze Janickiego w większości wypełnione są treścią aktualną, zaczerpniętą tak z jego życia osobistego, jak i z życia Polaków. W cyklach elegii przekazuje potomnym wiele informacji o swojej poezji, wierze i przyjaźni, o społecznej wartości literatury i nauki, medycyny i filozofii, o swoich mecenasach, nauczycielach i ludziach różnej kategorii. Rozprawia o miłości do ojczyzny i grożących jej aktualnie niebezpieczeństwach, o przyrodzie ojczystej i włoskiej, o wielu innych polskich i europejskich sprawach. Mówi o miłościwie panujących królach, Zygmuncie Starym i jego synu Zygmuncie Auguście. Sięga także do historii. W epigramatycznych zbiorach krótkich biografii poprzez dzieje polskich królów i arcybiskupów gnieźnieńskich daje szkic historii niemalże całego państwa polskiego. W nieporównanie mniejszym stopniu przedstawia treści służące wyłącznie literackiej zabawie, estetycznej rozrywce, erudycyjnym i retorycznym popisom. Mimo bowiem młodego wieku Janicki tworzył poezję poważną. Przychodził z pięknym słowem pulsującym realnym życiem, uchwyconym myślą i sercem poety ciężko chorego, ale już wyposażonego w duże doświadczenie, szeroką wiedzę o świecie i w ogromną wrażliwość człowieka religijnego, humanisty i trochę romantyka.

\section{Tradycyjna formacja religijna}

Janicki został ochrzczony najprawdopodobniej w parafialnym kościele w Górze, miejscowości w pobliżu Januszkowa. W wieku chłopięcym siłą rzeczy naśladował religijną postawę swoich rodziców i wiejskiego otoczenia, któ- 
re było katolickie. Co z religijności zawdzięcza domowi, o tym nie wspomina w swoich utworach, tak zresztą jak nic nie mówi również o swojej formacji religijnej w szkole parafialnej w Żninie, do której uczęszczał od piątego roku życia. Ale wiadomo skądinąd, że nauczyciel tego rodzaju szkółki miejskiej, oprócz czytania, pisania, rachunków, śpiewu, języka łacińskiego, uczył także zasad wiary. Różnie z tym bywało. Luteranin z Wielkopolski, Jan Seklucjan, równolatek Klemensa, pozostawił skomponowany po polsku wierszyk z 1547 roku na temat sposobu i treści nauczania w szkołach katolickich ${ }^{6}$ :
Jest mi to dziś na pamięci, Jak w szkołach uczono dzieci:
Od cum steteris poczynali; O Bogu mało wspominali, Ani o jego przykazaniu, Ani wiary świętej członków, Pacierza i sakramentów; Tych wykładu nie uczyli, A snadź sami nie umieli. [...] W niedzielę, abyś ministrował, A chędogo mszej pomagał.
Skoro dicentes usłyszysz, Tedy we dzwonek zadzwonisz, Kapłana byś nie rozgniewał, Kiedy będzie w Kanonie spał.

Ma się rozumieć, o czym Seklucjan pisze w dalszej części wiersza, całkiem korzystniej wyglądało nauczanie w szkole luterańskiej. Jakakolwiek by była rzeczywistość, Klemens jednak, o czym świadczy cała jego poezja, znakomicie przyswoił sobie katolickie zasady wiary i moralności. Zapewne i żnińska szkoła parafialna nie była tak zła, jak ogólnie opisuje to zagorzały zwolennik Lutra, i sam kościół farny, gdzie do dwunastego roku życia służył do mszy św., śpiewał w chórze nabożne pieśni i słuchał kazań, prawidłowo przekazywał mu zasady wiary. Prawdą jest, że o nauczycielach żnińskiej szkoły Klemens nie miał wysokiego mniemania. Jego katolicką formację kształtowały następnie Akademia Lubrańskiego w Poznaniu, dwór prymasa Krzyckiego oraz kontakty z wieloma ludźmi rzymskiego Kościoła. W każdym gatunku jego twórczości, czy to będzie elegia, czy epigram, czy skarga i satyra, czy pieśń weselna, nie mówiąc o parafrazie psalmu, znajdziemy mniejsze lub większe nawiązania do religii. Co w nich autor przekazał?

\footnotetext{
${ }^{6}$ Zob. A. Brückner, Dzieje kultury polskiej, Warszawa 1958, s. 171.
} 
Bóg Ojciec. Poeta z Januszkowa wyznaje żywą wiarę w Boga Ojca (Deus Pater), kochającego i miłosiernego. Czuje się jego niegodnym dzieckiem z powodu swoich grzechów i przyjmuje z pokorą karzącą rękę Najwyższego Władcy (summus Rex), czyli zesłaną na niego chorobę. Już w drugiej elegii zbioru, skierowanej do Matki Boskiej, pisze:

Tak spodobało się Najwyższemu Władcy, który w swej dobroci

Zbyt późno mnie karze za to, że Go obraziłem.

Na więcej, Ojcze, zasłużyłem; przez całe życie obrażam Ciebie.

Już dawno powinienem zejść do podziemnych wód.

Niczego bodaj nie pominąłem, co by w Ciebie nie godziło,

I, choć jestem twoim synem, byłem dla Ciebie wrogiem.

(Tr. 2, 63-68)

Owe podziemne wody to pogańskie wyobrażenie piekła. Ale Bóg Stwórca (Genitor) jest dla poety nie tyle sprawiedliwym sędzią, ile raczej cierpliwym i życzliwym wychowawcą. W karaniu bowiem postępuje jak matka, która lekkimi uderzeniami rózgi przywołuje do porządku swoje niesforne dziecko, aby uchronić je przed zagrożeniem (Tr. 2,69-79). Nawet bardzo cierpiący fizycznie poeta nie chce wytaczać skarg przeciw karcącemu Bogu Gromowładcy (tu użyje pogańskiej nazwy Jowisza - Tonans) ani bluźnić Najwyższemu Bóstwu (summum numen), bo wie, że zasłużył i na swoją chorobę, i nawet na śmierć $(\operatorname{Tr} .2,83-93)^{8}$.

Ludzi prawych i cnotliwych Bóg ratuje i wynosi do chwały, o czym świadczą biblijne przykłady Daniela w lwiej jamie czy Zuzanny fałszywie oskarżonej (Epigr. 21). Należy się jednak do Niego modlić o pomoc. Taką gorącą modlitwę do Boga Ojca o pokój i ład w państwie śle uosobiona Matka-Ojczyzna w „Skardze Rzeczpospolitej” (93-106):

Wielki Ojcze, który wzywasz, abym zgięty kark, obciążony

Zgubnym jarzmem, uwolniła od tego ciężaru,

Do Ciebie uciekam się pokornie, spójrz na mnie w tej burzy

I przyjdź mi z pomocą w beznadziejnej sytuacji.

Pokieruj łaskawie radami króla i głosami senatu

I wzbudź zdrowe myśli w rozdwojonym narodzie!

A tych, którzy są rzeczywistą przyczyną mojej boleści, Spal ogniem zesłanego z nieba gromu,

Aby byli przykładem dla innych i aby każdy nauczył się

Kochać własną matkę, tak jak Ty sam nakazałeś!

(Quer. 93-106)

\footnotetext{
${ }^{7}$ Przekłady, jeśli nie zaznaczono inaczej, pochodzą od autora artykułu.

${ }^{8}$ Por. G. Urban-Godziek, Elegia renesansowa. Przemiany gatunku w Polsce $i$ w Europie, Kraków 2005, s. 321n.
} 
Skarga to straszna, od takich modłów bieleje włos, jak powie Kornel Ujejski w znanej pieśni patriotycznej.

Szczególnym wyrazem wiary poety w Boga Ojca jest tzw. parafraza 70. psalmu Dawida Tobie, Panie zaufałem. Mówię ,tak zwana”, gdyż z biblijnego psalmu - In Te, Domine, speravi - Janicki wziął zasadniczo tylko przesłanie ogólne i dopasował je do swojej sytuacji śmiertelnie chorego człowieka9 ${ }^{9}$.

Poeta swoją dwakroć dłuższą pieśń zainspirowaną przez psalm zaczął od tego, że nie chciałby pokładać nadziei ani w bogactwach, ani w możnych ludziach tego świata, ,których ciemny thum otacza czcią niby największe bóstwa" (w. 9). Cała nadzieja, zarówno w burzliwym, jak i spokojnym okresie jego życia, złożona jest w ręku Boga, który pysznych poniża, a maluczkim udziela swojej łaski i wynosi ich aż na same szczyty. Starożytność pogańska dostarcza na to wiele przykładów. Jednym z nich jest znany nam dobrze Krezus, ostatni król Lidii w Azji Mniejszej, chlubiący się bogactwami i pochodzeniem, który ostatecznie poniósł totalną klęskę, drugim - mityczny Gordios, który jadąc na skromnym wozie, osiągnął królewski tron w pobliskiej Frygii. Słabego człowieka, gdy ten w ufnej modlitwie prosi Boga o pomoc, Bóg otacza opieką przed najbardziej potężnymi i niszczycielskimi żywiołami. W tym przypadku poeta sięga po świadectwa do Biblii; oto umierający Ezechiasz otrzymuje przedłużenie życia o piętnaście lat, a Daniel wrzucony do jaskini lwów nie doznaje żadnej szkody. Na tego rodzaju Boże działanie - dodaje autor - można by przytoczyć niezliczoną rzeszę innych ludzi. Następnie prosi, aby mógł się znaleźć w gronie tych, którzy otrzymują ocalenie i mieszkanie w domu Ojca, aby dobrotliwy Ojciec otoczył go murem bezpieczniejszym od babilońskich murów mitycznej królowej Semiramidy i zapewnił mu spokój, zwłaszcza wtedy, kiedy już nadejdzie śmierć z głową spowitą w ciemności i kiedy jego ciało spocznie w grobowej jamie wśród robactwa, a do nieba uleci jego lepsza część, czyli dusza (w. 100 nn.).

Śmierci nie należy się bać. To samo głosił poeta już we wcześniej napisanej elegii do Najświętszej Marii Panny. Przeczuwając bliską śmierć, kończy swoją przeróbkę psalmu modlitwą błagalną do Boga Ojca:

Święty Ojcze, Królu i Boże, który jasne stworzyłeś Gwiazdy i wszystko, co wszechświat ogarnia,

Oto natura zgodnie ze swym prawem przyspiesza koniec Memu życiu, bo przeminęły szybko mknące dni. [...]

Niech moja dusza nie zginie bez pasterza, niech wezwana do owczarni Nie lęka się krwawej paszczy wściekłego wilka!

${ }^{9}$ I. Lewandowski, Poeta laureatus..., s. 178-179; zob. A. Modlińska, Indywidualizacja wyznania modlitewnego w poetyckiej parafrazie psalmu ,In te, Domine, speravi” Klemensa Janickiego, Studia Classica et Neolatina, t. 6, Od Średniowiecza po Oświecenie, Gdańsk 2004, s. 75-83. 
Ta dusza, co pod Twoją opieką tylekroć uszła spod paszcz dzikich zwierząt,

Niech teraz nie będzie wydana na poszarpanie dzikiej bestii!

Ty bowiem jesteś prawdziwym Ojcem i z miłością prawdziwego ojca

Odnieś się, proszę na kolanach, do Twojego potomka.

Dlaczego mam się lękać, jeśli całą mą ufność pokładam w Tobie,

Który będziesz na zawsze radował mnie i wspierał?

(Coll. 11, w. 105-112)

O opiece Boga Ojca nad królem Zygmuntem Starym i powierzoną mu Rzeczpospolitą Janicki wypowiada się wiele razy w Pieśni weselnej na cześć Zygmunta Augusta (Epith.), napisanej w ostatnich miesiącach przed śmiercią. Podkreśla w niej wielką pobożność króla, przejawiającą się w jego modlitwach, w dbałości o kult, o świątynie i duchowieństwo. Za to Bóg i całe Niebo wynagradzały króla i naród zwycięstwami na polu bitwy, darzyły pokojem i dobrobytem, a ostatecznie pozwoliły także udręczonemu poecie to wszystko opiewać (Epith. 195-220). Królowi Zygmuntowi Augustowi poeta radzi, aby dążył do sławy swojego ojca, którą Bóg może jeszcze pomnożyć, ale przy zachowaniu pewnych warunków:

Ty tylko przestrzegaj sprawiedliwości; jest to dar dla królów Szczególny i Bóg Najwyższy nie ma dla nich nic lepszego.

Nad kult religijny niech nie będzie dla ciebie nic ważniejsze; on był Najważniejszy dla twoich dziadów, najważniejszy dla ojca.

(Epith. 2,95-98)

Skoro Janicki tak gorąco zalecał innym pielęgnowanie kultu religijnego, to trudno przypuszczać, by w swoim życiu praktycznym miał się do niego nie stosować i jego zasady przyjmować tylko teoretycznie.

Syn Boży. Poeta często przywołuje drugą Osobę Trójcy Świętej, Chrystusa. Jego imię przewija się we wszystkich gatunkach uprawianej przez niego poezji; w „Smutnych elegiach” znajdujemy je 7 razy, w „Epigramach” 6 razy, w „Żywotach królów” - 4 razy, w „Żywotach arcybiskupów” - 1 raz, w „Pieśni weselnej” - 1 raz.

Chrystus jako Bóg ukrzyżowany, litując się nad pogańskimi owieczkami, przybył do Polski za panowania Mieszka I, aby wybawić je spod władzy szatana (Reg. 17). Tylko Chrystus posiada moc uzdrawiającą człowieka z najcięższej choroby ciała i tylko On, gdy taka jest Jego wola, może także uzdrowić poetę z puchliny wodnej, na którą nie mają siły nawet najlepsi lekarze (Tr. 7,166).

Tenże Chrystus i wierzący w Niego lud doznaje aktualnie upokorzenia ze strony mahometan, którym prawdziwi chrześcijanie, potrafiący dźwigać 
z pokorą Jego krzyż, powinni mimo to stawić zdecydowany opór ( $\operatorname{Tr}$. 8,90; $147 ; 11 ;$ Coll. 7). Janicki, tak jak wielu innych polskich i europejskich poetów i pisarzy, poświęcił tej kwestii dużo miejsca w swojej twórczości, zwłaszcza w trzech elegiach „Księgi żalów” (Tristium liber): w szóstej, ósmej oraz dziewiątej. Gorąco w nich wzywa chrześcijańskich książąt Europy do zgody i wspólnej walki przeciw muzułmańskim zagonom, przedstawia kolejno smutne i coraz bardziej tragiczne postępy tureckiego oręża, a szczególnie ubolewa nad zajęciem bratnich Węgier. W elegii szóstej ostrzega, że waśnie i rozdarcie stwarzają podatny grunt dla tureckiej agresji, w ósmej natomiast z epicką wylewnością, ale i w rozpaczliwych słowach uosobionej stolicy Węgier, Budy, daje poruszający opis najazdu i zbezczeszczenia chrześcijańskiej religii. Podobny los wieszczy innym krajom. Wreszcie w elegii dziewiątej przedstawia całkiem już realną groźbę tureckiego podboju także dla Polski, jeśli ta nie wyruszy zaprzyjaźnionym Węgrom z pomocą. Woła:

Dobro Panonii waszym jest także dobrem, Polacy,

Sarmata na wspólnej z nią płynie łodzi.

Dopóki ona była nietknięta, przedmurzem była

Tak polskiej, jak i niemieckiej ziemi.

Skoro upadła, to jakiej mamy się spodziewać przyszłości?

Milczy mój język z lęku przed złą wróżbą.

Język milczy, ale rozum i rzeczywistość mówią o groźbie;

$\mathrm{O}$, niech wiatry rozproszą wszelkie moje lęki!

(Tr. 9, 139-146)

Mimo tych twardych i groźnych słów zadziwia nas Janicki usprawiedliwianiem rycerza i polityka, Hieronima Łaskiego, który szuka pomocy u wrogów Chrystusa, czyli tureckich muzułmanów, aby pozyskać dla Jana Zapolyi, władcy Siedmiogrodu, pomoc sułtana przeciw chrześcijańskiemu cesarzowi, Ferdynandowi I (Tr. 9,43). Jak się przypuszcza, ulega tu poeta nieco ugodowej polityce Zygmunta Starego wobec Turcji.

W „Epigramach” Janicki ukazuje przede wszystkim miłość do Chrystusa jako Człowieka, który cierpi z powodu swojej zbawczej misji tak skutecznie szarpanej przez sztuczki podziemnego bożka, czyli diabła. Urzeka swoją plastycznością wiersz „Na wizerunek Chrystusa siedzącego na kamieniu” (Epigr. 7):

O czymże dumasz, zmęczony Chrystusie, siedząc mizernie

$\mathrm{Na}$ twardym kamieniu i łokciem wspierając swą głowę?

Pewnie o zbawczym dziele, o więzach dla umierającej śmierci ${ }^{10}$,

${ }^{10}$ Niejasne: morienti vincula morti; może znaczy to „o więzach dla umierającego sprawcy śmierci"; mors to ten, co przynosi śmierć. 
O łupach i mrocznym królestwie podziemnego bożka ${ }^{11}$. Daj, proszę, niech o tym samym myślę, dopóki żyję, i niech Twoja dłoń łaskawa wesprze moją znękaną głowę.

Kilka epigramów poświęca poeta osobom związanym z działalnością Chrystusa Zbawiciela. Oglądał je zapewnie na malowidłach w kościołach i biskupich pałacach, a następnie kazał w poetyckim słowie zwięźle przemawiać i zgrabnie formułować puenty z religijnym i moralnym przekazem. Niech nam to zilustrują przykłady:

„Na wizerunek łotra po prawicy” - In imaginem latronis dextri (Epigr. 14):

Jedno słowo dało mi życie po najgorszym życia

Okresie. Któż może wątpić w dobroć Bożą?

„Na wizerunek Zacheusza” - In imaginem Zachaei (Epigr. 15):

Przyjmijcie Chrystusa w gościnę wy, których brzemię grzechów

Przytłacza. On przyszedł szukać zbłąkanych owiec.

„Na wizerunek Mateusza Ewangelisty” - In imaginem Mathaei Evangelistae (Epigr. 16):

Ja, poborca podatkowy, na wezwanie Chrystusa wszystko rzuciłem.

Tak, proszę, uczyń, jeśli wyższych pragniesz dóbr!

„Na wizerunek Piotra Apostoła” - In imaginem Petri Apostoli (Epigr. 17):

Oto ja, klucznik Tego, którego się wyparłem.

Wszelki występek zmywają szczere łzy.

„Na wizerunek Pawła Apostoła” - In imaginem Pauli Apostoli (Epigr. 18):

Gdy światłość zwalczałem, Boża światłość wezwała mnie

Do tej światłości, którą poniosłem narodom.

„Na wizerunek Marii Magdaleny” - In imaginem Mariae Magdalenae (Epigr. 19):

W występkach nurzałam się przez wiele lat.

Kres im położyły cierpienie, płacz i miłość.

„Na wizerunek Longina żołnierza” - In imaginem Longini militis (Epigr. 20):

Zabiłem Pana i otrzymałem wzrok i wiarę;

Opłaciło mi się, o dobroci, być okrutnikiem.

${ }^{11} \mathrm{~W}$ tekscie: Stygijski bożek to nikt inny, jak „chrześcijański” diabeł, bo starożytne podziemie, gdzie płynęła rzeka Styks, nosiło w tym czasie nazwę „chrześcijańskiego” piekła. 
O Chrystusie ukrzyżowanym mówi epigram nagrobny, jakim poeta uczcił swego ojca (Epigr. 39). Zasadniczą jego treść bowiem stanowi podstawowa nauka wiary o odkupieniu płynąca z krzyża Chrystusowego. Życiodajne drzewo krzyża na grobie jest więcej warte niż marmurowa lub spiżowa kolumna czy wyniosła jak piramida budowla. Na nim bowiem Bóg przełamał władzę piekielnego tyrana, słowem, przyniósł rodzajowi ludzkiemu odkupienie od grzechów. Poeta zwraca się do swego ojca:

Najlepszy ojcze, ja, twój syn, tę zbożną ofiarę tobie Złożyłem, zgnębiony i łzami zalany.

Nie z paryjskiego to marmuru ani ze spiżu kolumna,

Ani chełpliwa budowla wysokiej piramidy,

Ale życiodajne drzewo krzyża, którym Bóg skruszył

Żelazne rządy piekielnego tyrana,

Gdy grasującą śmierć swoją śmiercią zwycięsko pokonał

I ojców uwolnił z więzów okrutnej otchłani.

Spójrz, przechodniu, za jaką cenę odkupione twoje życie!

Niechaj twoje grzechy rzadziej nim kupczą!

Postaci Chrystusa jako Boga i Człowieka dotyczy epigram-zagadka: pierwsza część zawiera paradoksalny problem do rozwiązania: zrodziła mnie matka, lecz ja stworzyłem ją wcześniej. Druga zaś część w formie poziomego akrostychu po złożeniu liter daje rozwiązanie w imieniu: Chrystus (Epigr. 40) ${ }^{12}$.

Na temat trzeciej Osoby Trójcy Świętej, czyli Ducha Świętego, nie znajdujemy w poezji Janickiego żadnych wypowiedzi.

Matka Boska. Szczególne miejsce w poezji Janickiego zajmuje Maria Dziewica (Virgo Maria), gdyż chory poeta uczynił Ją adresatką drugiej elegii w zbiorze Tristia, której nadał tytuł Poeta modli się do Najświętszej Marii Dziewicy, aby wyjednała mu cierpliwość i męstwo podczas febry kwartanki, na jaka zapadt w Padwie. W niej poeta odsłania nam niezachwianą wiarę w opiekę oraz wstawiennictwo Marii Wspomożycielki (Adiutrix), córki i rodzicielki Najwyższego Boga (summi nata parensque Dei). Wyraża - przypomnijmy wiarę tak charakterystyczną od wieków dla polskiej nacji, której pieśń Bogurodzica, Dziewica była hymnem państwowym. Mimo szerzącego się wówczas protestantyzmu, niechętnemu - jak wiadomo - kultowi maryjnemu, nasz autor właśnie w Matce Boskiej pokłada nadzieję na zachowanie go przy życiu na włoskiej ziemi. Do Niej więc płyną rzewne słowa modlitwy błagalnej i dzięk-

${ }^{12}$ Akrostych to utwór wierszowany, w którym występuje taki układ liter, że tworzy się dodatkowy napis. Znamy wiele kombinacji takich układów: pionowe, poziome, ukośne i inne. U Janickiego mamy akrostych poziomy: Carmen Habes: Res Ipsa Subit, Trina, Una, Suprema. - Oto masz zagadkę; sama treść ją rozwiązuje: Troistość, Jedność, Najwyższa Istota. 
czynnej zarazem. Najpierw, jak ten żebrak pod bramami, prosi o zdrowie dla ciała, skoro moc ludzkiej sztuki medycznej, nawet tej najlepszej, padewskiej, nie jest zdolna przyjść mu na ratunek.

O moja Wspomożycielko, zawsze tak niezawodna we wszelkich

Udrękach, Córko i Rodzicielko najwyższego Boga,

Teraz także, teraz zwróć łaskawie z nieba na mnie swoje oczy

I przyjmij, o Najświętsza, błagalne modlitwy twego sługi.

Następnie dziękuje za to dobro, jakie mimo ciężkiej choroby dzięki Matce Boskiej jeszcze mu pozostało:

To, że może się żalić na swój los, że dotąd nad swoją mową Zupełnie panuje, Tobie to wszystko zawdzięcza.

Zawdzięcza również tę odrobinę ducha, która pod tą skórą I wśród tych żył i wśród tych kości jeszcze się kryje.

(Tr. 2,15-18)

Nie tylko jednak myśli on o swoim fizycznym zdrowiu, ale także o wiecznym zbawieniu. Pieśń ta bowiem przeplatana pokutnymi westchnieniami do Boga Ojca kończy się prośbą, aby Dziewicza Matka (Virgo) pozwoliła mu, gdy taka jest już ostateczna wola Najwyższego, pogodnie przyjąć śmierć, która nie jest tak straszna, jak się ją maluje, i aby wówczas jako Królowa (Regina) wprowadziła jego duszę do nieba i posadziła w gronie aniołów. Niech wyrażą to słowa samego poety w thumaczeniu Zygmunta Kubiaka, wielkiego znawcy i wielbiciela poety z Januszkowa:

Ty zaś, Dziewico, racz się modlić o to, Bym umiał mężnie znosić te cierpienia I nie narzekał, nie zwał bezlitosnym Pana (tak nieraz się bełkocze w bólu) I bym miał za nic tę mękę, przyznając, Że zasłużyłem na surowszą karę.

Niech i śmierć witam pogodnie, jeżeli

Już teraz ku mnie cichą stopą kroczy.

Bo czemuż miałaby się wydać straszną,

Gdy raczej wzywać jej trzeba - z dwóch przyczyn:

Zabije ciało, nie pozostawiając

Mocy grzeszenia przeciw Najwyższemu,

A ducha z mroków wyrwanego odda

Niebu. O gdybyż było to już bliskie! 
Ujrzę oczyma, czego nawet myślą

Nie umiem pojąć i wyrazić w słowach;

Ciebie i duchy Twoje. I pozwolisz mi,

Bym u dostojnych zasiadł stóp, Królowo.

Jakże mam wątpić w to, gdy w burzach życia

Zawsze troskliwie nade mną czuwałaś?

Racz nie opuszczać mnie, póki się w morzu

Szamoczę tego zwodniczego świata.

$(\operatorname{Tr} .2,81-102)^{13}$

Oto piękna modlitwa młodego i udręczonego poety!

Życie pozagrobowe. W ostatnich wierszach tej modlitwy poeta wyraził także silną wiarę w życie pozagrobowe, do którego wprowadza Matka Boska, patronka dobrej śmierci. Miłosierny Ojciec i Maria Wspomożycielka obdarzają duszę ludzką szczęściem nieogarnionym przez ludzki rozum. Nie godzi się więc ufać - pisze na innym miejscu (Coll. 10,5-6) - uludnym sprawom ziemskim, bo tylko czysty duch ulatuje do niebieskich siedzib.

W elegii autobiograficznej chory poeta, niby żegnając ostatni raz swego lekarza i przyjaciela, Antonina ${ }^{14}$, wyznaje swoją wiarę w świętych obcowanie:

Jedno, co mi wolno; gdy znajdę się wśród duchów i radosne zastępy Świętych przyjmą mnie do swego grona, będę mówił o tobie...

Bo ty przyjdziesz do mnie, jak przyjdą wszyscy, których zostawiam; Tutaj losy nikomu nie dały wiecznego mieszkania.

(Tr. 7, 149-151; 183-184)

Tę wiarę wyraził także w kunsztownym i głęboko refleksyjnym epitafium, które polecił wypisać dużymi literami na swoim grobie:

Od nadziei wolny i wolny od lęku spoczywam pod tym głazem I prawdziwie żyję. Śmiertelny żywocie, żegnaj!

(Tr. 7,89-90)

Wierząc w życie pozagrobowe i jego uroki, renesansowy poeta nie dezawuuje piękna ziemskiego życia ani chęci korzystania z niego. W epigramie do znajomego historyka, Justusa Decjusza (ok. 1485-1545), który był już w podeszłym wieku, a miał piękny pałac zbudowany w malowniczym zakątku pod Krakowem, stawia pytania:

${ }^{13}$ Zob. Klemens Janicjusz, Poezje wybrane. Wybrał, przełożył i wstępem poprzedził Zygmunt Kubiak, Warszawa 1975, s.25n.

${ }^{14}$ Znaczne pogorszenie zdrowia nastąpiło jesienią $1541 \mathrm{r}$, puchlina wodna robiła postępy. 
I czemu ty, Juście, spieszysz się do nieba? Czemu chcesz szybko Ulecieć do owych przyjemności, jakie posiada raj?

Tutaj żyj długo dla mnie, żyj dla swoich! Nawet raj nie może mieć Ich więcej, niż posiada ich twoja wieś Wolą nazwana.

(Coll. 5)

Święci polscy. Poza wyżej wspomnianymi osobami, związanymi ściśle z historycznym Chrystusem, Janicki ukazał jeszcze tylko dwóch świętych, mianowicie Wojciecha i Stanisława, patronów Polski.

W krótkim epigramie Żywotów arcybiskupów gnieźnieńskich zwrócił uwagę na żywy kult św. Wojciecha w Gnieźnie, jako na promieniejący przykład człowieka oddanego bożej sprawie aż do męczeństwa. W słowach poety wyczuwa się pewne ubolewanie, że współczesnym ludziom brakuje silnej wiary, którą posiadał św. Wojciech. Dlatego w apostrofie do Gniezna stawia same retoryczne pytania (Arch. 4):

Jaki był Wojciech, dlaczego pytasz, o Gniezno?

Czy nie widzisz szczęścia z grobu świętego męża?

Kto za życia dokonuje tyle, ile dokonuje on po śmierci?

Kto teraz znosi tyle dla swego Pana, ile on zniósł?

Drugi epigram, znacznie dłuższy, umieścił w Żywotach polskich królów (Reg. 19) tuż po Bolesławie Chrobrym. Miejsce to wyznaczyły św. Wojciechowi zapewne ścisłe więzy, jakie łączyły go z królem, ale i rola patrona nadawała mu niejako królewską rangę. Poeta podaje tu informacje o wypędzeniu biskupa z Pragi i jego pobycie w Gnieźnie, o misji pruskiej, czyli sprowadzaniu pogańskiego ludu na Chrystusową drogę (w. 6) i męczeńskiej śmierci, o wykupieniu ciała i oddawaniu mu czci, o cudach i znakach nad grobem. Autor pisze, że Wojciech wygnaniec:

Był pożyteczny przykładem swego życia i uczoności, był mężem

Znakomitym we wszelkiej chwale prawdziwej pobożności.

(Reg. 19,3-4)

Jak przy biogramie króla Bolesława Chrobrego poeta umieścił żywot Świętego Wojciecha, tak przy biogramie króla Bolesława Śmiałego z tych samych powodów umieścił żywot Stanisława biskupa (Reg. 23). Opiewa w nim jego męczeńską śmierć za swoje owieczki, jaką z rąk szalonego króla poniósł biskup podczas sprawowania ofiary chleba i wina. Pocięte szczątki ciała kazał bestialski król porozrzucać po polach jako pokarm dla ptactwa. Stał się jednak cud i członki zrosły się w poprzednią całość. Tyle o Matce Boskiej i świętych Pańskich w poezji Klemensa! 
Szatan i piekło. Z wiarą katolicką wiąże się także postać szatana. Poeta nie wątpi w jego istnienie i niecne działanie na świecie, lecz wspomina go rzadko. Szatan posiada władzę nad poganami i miał ją nad przodkami Polaków, zanim nie przyjęli chrztu (Reg. 17,2). On zawsze sprzeciwia się zbawczej misji Chrystusa, który jednak przez swój krzyż złamał i ujarzmił żelazną władzę piekielnego tyrana (Epigr. 7,4; 39,6). On pobudza obywateli do zamieszek i obłąkańczych posunięć przeciw ojczyźnie (Proc. w. 6). Ludzi beznadziejnie złych, rozpustników, grabieżców, morderców i przynoszących tylko hańbę szatan porywa i topi w piekielnych bagnach (Reg. 22,12; Coll. 1,6). Janicki stosuje do niego, tak jak inni pisarze tego okresu, terminologię, jaką starożytni nazywali podziemne bóstwo, a więc: Stygius deus - stygijski bożek (Epigr. 7,4), Stygius tyrannus - stygijski tyran (Epigr. 39,6), Stygium numen - stygijskie bóstwo (Ad Proc. 6), hostis Stygius - stygijski wróg (Reg. 17,2) ${ }^{15}$. W kilku miejscach używa nazwy $\operatorname{Orcus}$ (Reg. 22,12; Epigr, 10,1; Tr. 7,159), gdyż w mitologii rzymskiej jest to nazwa boga śmierci. Podobnie słowami antycznych pisarzy określa królestwo szatana, czyli piekło: Stygia palus - stygijskie bagno (Var. el. 3,40), Stygiae aquae - stygijskie wody (Reg. 22,12).

\section{Janicki wobec duchowieństwa}

Przyglądając się kościelnemu aspektowi religijności poety, musimy stale pamiętać o wielkim wstrząsie i zamęcie, jaki wówczas w Kościele katolickim czyniła reformacja. Swoją nauką uderzała ona głównie w pasterzy tegoż Kościoła, aby rozproszyć jego owieczki. Janicki dzięki przebywaniu na dworach wpływowych mecenasów i dzięki swej pracy nad żywotami arcybiskupów posiadł dostateczną wiedzę tak o życiu i postawie, jak i dawnej działalności wielu duchownych hierarchów w Polsce, a poniekąd także w innych krajach europejskich, zwłaszcza we Włoszech. Miał na ten temat wyrobiony pogląd i wyrażał go w swojej poezji - w elegiach i epigramach, jeśli chodzi o aktualny stan rzeczy, w epigramach biograficznych, gdy bierzemy pod uwagę aspekt historyczny.

Prymas Krzycki (1535-1537) był dla niego najlepszym mecenasem, przedstawicielem wszelkich zalet ducha, tradycyjnej pobożności i wiary, umiaru i łaskawości, pogody ducha i powagi. Należy cenić jego twórczość literacką oraz dbałość o rozwój sztuki i nauki, dzięki czemu ojczyzna urosła do rangi wysoko cywilizowanych krajów (Var. 1). Krzycki z wielką troską starał się, by nie dopuścić do rozłamu w Kościele i przepędzić z owczarni „straszne wilki”, czyli agitatorów reformacji (Var. 1,75-80; Epigr. 26; Arch. 43).

${ }^{15}$ Stygijski, Stygius, przym, od Styx, gen. Stygis, mit., Styks to najważniejsza rzeka czy bagno w podziemnej krainie Hadesa; podziemie. 
Z zagranicznych hierarchów wysoko oceniał włoskiego kardynała Piotra Bembo, człowieka renesansu, któremu poświęcił całą elegię w cyklu „Różnych elegii” (Var. 9). Podkreślał w niej humanistyczne cnoty hierarchy, a więc latyńską prawość, wdzięk i uczynną życzliwość, chwalił skromność i prostotę, wynosił nad starożytnego Cyncynnata, który prosto od pługa został powołany na dyktatora (Var. 9,43-44; 59-69). Janicki był gościnnie zapraszany na uczone sympozja do jego wspaniałych ogrodów (Epigr. 52).

Sięgając do historii, podobnie wysoko jak Krzyckiego oceniał prymasa Jana Łaskiego (1510-1531; Arch. 41):

Umiłowany syn wiary, ojciec ojczyzny, twórca twojej, Gniezno,

Godności, sama czystość i pobożność, to prymas Łaski.

O święta jego śmierci tak bardzo podobna jego świętemu życiu! O, gdyby można, tak właśnie chciałbym umrzeć!

W Żywotach arcybiskupów gnieźnieńskich ${ }^{16}$ potrafił także przekazać rażące wady duchownych dygnitarzy, o których źle mówiły źródła historyczne, czyli w tym wypadku Jan Długosz. Skumulowały się one w arcybiskupie Janie Gruszczyńskim (1464-1472). Pisze o nim:

Wyuzdany, rozpustny, zniewieściały, gotowy na wszelki Występek i niegodziwość był Gruszczyński.

Gdy w nocnej porze pił i śpiewał przy kościelnych świecach,

Niebacznego nagle i niespodzianie śmierć porwała.

(Arch. 36)

Trzeba tu powiedzieć, że Janicki jeszcze jako student Akademii Lubrańskiego, gdzie jego nauczycielem był między innymi luteranin Krzysztof Hegendorf, puszczał w obieg razem $\mathrm{z}$ innym kolegą - oczywiście anonimowo - zniesławiające wiersze na kapitułę poznańską czy niektórych mniej lubianych jej członków. W „Epigramach” umieścił zjadliwe wierszyki na kanonika Tomasza Rożnowskiego, administratora diecezji krakowskiej, za jego pazerność (Epigr. 6), na pewnego kapłana i zakonników za ich kłopoty z zachowaniem czystości (Epigr. 23;24). Jego antymonachizm, modny zresztą wśród renesansowych poetów, objawił się dość wyraźnie w jednej elegii padewskiej (Var.11), w której - niby jakiś zdecydowany luteranin - kpi sobie z franciszkańskiego nauczyciela filozofii, dlatego że ten radzi mu zająć się nauką Dunsa Szkota. Ma dla niego propozycję, aby zamiast unosić się ze swoją filozofią

${ }^{16}$ O Żywotach..., więcej zob. I. Lewandowski, Janickiego epigramy o arcybiskupach gnieźnieńskich, w: Polonia Latina. Szkice o literaturze tacińskiej w dawnej Polsce. Do druku podali A.W. Mikołajczak, K. Dominas i M. Miazek-Męczyńska, Gniezno 2007, s. 88-104. 
w obłokach, jak Dedal i Ikar, pofrunął na skrzydłach Kupidyna do franciszkańskich mniszek, bynajmniej niestroniących od światowych uciech (Var. 39-46). Ta nazbyt śmiała wypowiedź studenta o swoim nauczycielu była zapewne inspirowana uniwersytecką atmosferą w Padwie, a wcześniej stosunkami na dworze mecenasa Kmity, dosyć przychylnym dla religijnych nowinek. Chociaż istnieje też inne przypuszczenie, że mianowicie adresatem tych słów nie był profesor, lecz kolega, student filozofii.

Janicki więc nie stronił od krytycznego spojrzenia także na duchownych, mimo że im w dużej mierze zawdzięczał swoją karierę. To najprawdopodobniej kanonik gnieźnieński, Stanisław Kilowski, doradził rodzicom posłanie go na studia do Poznania, następnie polecił go mecenasom, najpierw Krzyckiemu, a później Kmicie. Po powrocie z Włoch, nie mając już mecenasów, Janicki czerpał korzyści z kościelnej prebendy, jaką było probostwo w Gołaczowie, które przynosiło mu pewien dochód. Czuł się jednak człowiekiem niezależnym i nie szczędził słów ostrej krytyki również pod adresem historycznych królów polskich czy aktualnie rządzącej szlachty i magnaterii.

\section{Podsumowanie}

Przytoczone z utworów Janickiego teksty dotyczące motywów religijnych i pośrednio jego religijności zdecydowanie świadczą o katolickim profilu wyznawanej wiary. Pojawiające się w nich niekiedy słowa krytyczne nie dotyczą samych prawd wiary, lecz przestrzegania ich w praktyce codziennego życia, i wskazują raczej na intelektualną i emocjonalną sympatię dla nich oraz na troskę poety o jednoznaczność ludzkich postaw niezależnie od społecznego statusu. Luterańskie wpływy, widoczne w niektórych wypowiedziach, były niewielkie. Otwarcie nie wypowiadał się na ten temat ani za, ani przeciw, mimo że jego pierwszy mecenas, prymas Krzycki, był zdecydowanie przeciwnikiem luteranizmu. $Z$ całą mocą natomiast występował przeciw islamowi szerzącemu się w Europie przez zbrojne najazdy. Chociaż w terminologii związanej z religią używa słownictwa starożytnych Rzymian, jednak nadaje im znaczenie chrześcijańskie, jak to zresztą nagminnie czynili pisarze renesansowi, zwłaszcza poeci. Znając na wylot filozofię i ducha starożytnego świata, nie identyfikował się z nim w kwestiach wiary i moralności. Wiara Janickiego jak to wynika z przedstawionych wątków - była dojrzałą katolicką wiarą renesansowego intelektualisty, a nie cichego i pokornego syna chłopa z Januszkowa pod Żninem. 


\section{RELIGIOUS THEMES IN THE WORKS AND LIFE OF KLEMENS JANICKI}

(1516-1543)

\section{Summary}

Klemens Janicki (1516-1543), arguably the greatest Latin poet in Poland, is little known to the people of our times. He was a citizen of Greater Poland, born in Januszkowo near Żnin. In each of the genres practiced by him, be it elegy or epigram, complaint or satire, or wedding song, not to speak of the paraphrase of the psalms of David, we find minor or major references to religion. What did the author convey in them? Beautiful images of faith in God the Father, the humanity of Christ, the powerful intercession of the Most Blessed Virgin Mary; depictions of the holy Polish martyrs, Adalbert and Stanislaus; the author's own attitude to historical and his contemporary representatives of the Church. These images give preeminent evidence of the Catholic profile of the faith professed by Janicki. The occasional critical words do not pertain to the truths of faith as such but to inadequate obedience of them in everyday life, so the criticism indicates the poet's intellectual and emotional support of those truths and his concern for an explicitness of people's attitudes irrespective of their social status. Lutheran influences are scarce in his works, though noticeable in some utterances. He was strongly opposed to Islam which was then spreading through armed invasion. Being versatile in the philosophy and spirit of the ancient world he did not identify with it in questions of faith and morality. Janicki's faith - as can be gathered from the presented themes - was the mature Catholic faith of a renaissance intellectual and not that of a meek and humble son of a peasant from Januszkowo near Żnin.

Słowa kluczowe: Klemens Janicki, wątki religijne, luteranizm, islam, duchowieństwo

Keywords: Klemens Janicki, religious themes, Lutheranism, Islam, clergy

\section{BIBLIOGRAFIA}

\section{WYDANIA I PRZEKLADY}

Clementis Ianicii poetae laureati Carmina. Edidit... L. Ćwikliński, Cracoviae 1930.

Klemens Janicki, Carmina. Dzieła wszystkie. Wydał i wstępem (I) poprzedził J. Krókowski, przełożył E. Jędrkiewicz, wstęp (II), komentarz, similia, appendices, słownik imion własnych i indeks oprac. J. Mosdorf, Kraków 1966.

Klemens Janicjusz, Poezje wybrane. Wybrał, przełożył i wstępem poprzedził Zygmunt Kubiak, Warszawa 1975.

Medytacje Janicjusza. Wybór, wstęp, przekład, komentarz Z. Kubiak, Warszawa 1993. 


\section{OPRACOWANIA}

Brückner A., Dzieje kultury polskiej, Warszawa 1958, t. 2.

Ćwikliński L., Poeta uwieńczony, 1516-1543, Kraków 1893.

Kuehn A., Zdrowie Klemensa Janickiego z apteka w tle, Żnin 2016.

Lewandowski I., Poeta laureatus czyli Życie i dzieło Klemensa Janickiego, [krótki wybór poezji w polskim przekładzie oraz ilustracje], Żnin 2016.

Lewandowski I., Janickiego epigramy o arcybiskupach gnieźnieńskich, w: I. Lewandowski, Polonia Latina. Szkice o literaturze tacińskiej $w$ dawnej Polsce. Do druku podali A.W. Mikołajczak, K. Dominas i M. Miazek-Męczyńska, Gniezno 2007.

Modlińska A., Indywidualizacja wyznania modlitewnego w poetyckiej parafrazie psalmu ,In te, Domine, speravi" Klemensa Janickiego, Studia Classica et Neolatina, t. 6, Od Średniowiecza po Oświecenie, Gdańsk 2004.

Sawicki S., Matka Boska w poezji średniowiecza i renesansu, w: Matka Boska w poezji polskiej, t. I, Lublin 1959.

Stawecka K., Religijna poezja łacińska XVI wieku w Polsce. Zagadnienia wybrane, Lublin 1964. Urban-Godziek G., Elegia renesansowa. Przemiany gatunku w Polsce i w Europie, Kraków 2005. 